\title{
Physicochemical characteristics of forest soils in Tarai and Siwalik regions of Nepal
}

\author{
Ramesh P. Sapkota ${ }^{1,2^{*}}$, Peter D. Stahl ${ }^{1}$ and Kedar Rijal ${ }^{3}$ \\ ${ }^{1}$ Department of Ecosystem Science \& Management and Program in Ecology, University of Wyoming \\ 1000 E University Avenue, Laramie, WY, USA \\ ${ }^{2}$ Department of Environmental Science, Amrit Campus, Tribhuvan University, Kathmandu, Nepal \\ ${ }^{3}$ Central Department of Environmental Science, Tribhuvan University, Kathmandu, Nepal
}

\begin{abstract}
Soils are important components of every terrestrial ecosystem. In Nepal, terrestrial ecosystems of Tarai and Siwalik regions are highly vulnerable due to intense anthropogenic disturbances. Forest depletion and land degradation have posed substantial impacts on soil quality. This review paper focuses on identifying the status of physical and chemical characteristics of forest soils in Tarai and Siwalik regions. For the purpose, published articles from various sources, as well as publications of Government of Nepal were reviewed. The study showed variation in physicochemical characteristics of soils in different regions. The land areas covered with vegetation were found effective in controlling erosion and consequently retention of important chemical properties of soils. The scientific studies on soil physical, chemical and biological quality seem inadequate. Standard research framework and sampling designs are required in future studies, so that comparisons on soil properties across different degraded and/or other land-use categories can be made. There is need of development of scientific database on soil quality for supporting future ecosystem management and restoration programs.
\end{abstract}

Key words: Degradation, restoration, scientific database, soil quality

\begin{abstract}
Introduction
Determination of physical, chemical and microbiological aspects of soil are important for assessing soil metabolic properties and health of terrestrial ecosystems (Das \& Verma, 2011; Ewing \& Singer, 2012). Texture, structure, color, horizonation, consistence, density, porosity, aeration, water retention and movement are the major physical properties of soil (http://www.nrcs.usda.gov). Physical properties of soils affect root penetration, availability/adsorption of water by plants, availability of oxygen and other gases, and the degree to which water moves both laterally and vertically through the soil (Osman, 2013). According to Bhatnagar (1965), soil physical properties influence the stand, distribution, cover, rate of tree growth, vigor of natural reproduction and other silviculturally important factors (Paudel \& Sah, 2003), and below-ground carbon storage and strongly influences retention and availability of nutrients (Silver et al., 2000). Similarly, soil chemistry deals with the chemical processes ongoing on soils including the mineralization of macro-nutrients and micro-nutrients (Tan, 2011). Among the chemical properties, pH, salinity, cation exchange capacity, organic matter content and carbon to nitrogen
\end{abstract}

*Corresponding author, email address: rsapkota@uwyo.edu
(C: $\mathrm{N})$ ratio are of importance. Soil $\mathrm{pH}$ is known as "soil reaction" and indicates acidity or alkalinity in soil. Likewise, $\mathrm{pH}$ of water affects the ion solubility of soil, which directly affects the microbial and plant growth. The typical range of $\mathrm{pH}$ for soil is 4.0-9.0, but 6.0-6.8 has been considered to be ideal, as it is range of optimum solubility for the most important plant nutrients. Most of the metals with high molecular weight and some minor elements are more soluble at lower $\mathrm{pH}$ (Murad, 2012). The term salinity refers to the presence of the major dissolved inorganic solutes in aqueous samples. As applied to soils, it refers to the soluble and readily dissolvable salts in the soil or operationally, in an aqueous extract of a soil sample. Salinity is quantified in terms of total concentration of soluble salts, or more practically, in terms of the electrical conductivity of the solution, as both salinity and electrical conductivity are closely related.

Physicochemical characteristics of forest soils vary spatially and temporally due to variations in elevation, topography, climate, physical weathering processes, vegetation cover, microbial activities, and several other biotic and abiotic variables (Paudel \& Sah, 2003). 
Organic matter, being one of the most important constituents of soil, supplies energy and cell building constituents for most microorganisms and is a critical factor that enhances soil fertility. Soil quality relates the ability of soils to function effectively as a component of a healthy system (Schoenholtz et al., 2005).

Vegetation plays an important role in supplementing organic matter in soil and soil formation process (Chapman \& Reiss, 1992). Similarly, soil microorganisms play key roles in ecosystem processes mainly maintaining soil quality, functions and nutrient cycling. The major groups of microorganisms found in soil are bacteria, fungi, actinomycetes, algae, protozoa, metazoa and soil earthworms. These organisms are responsible for changing the physical, biological and chemical properties of soil. Moreover, microorganisms have the capacity to transform biomass and raw materials in soils (UNEP, 2009). Biomass, therefore, is both a source and sink of the nutrient contents in organic matter (FAO, 1993; Griffiths et al., 2012). Physical, chemical and biological components of soils are therefore very important in maintaining ecosystem's structure, functions, stability and dynamics. Therefore, in this paper, attempt has been made to better understand the qualities of soils in Tarai and Siwalik regions of Nepal and comparisons of soil quality across different land-cover and forestcover types. For the purpose relevant journal articles and various reports published from Government of Nepal, particularly from Ministry of Forests and Soil Conservation have been reviewed.

\section{Soils of Tarai and Siwalik region}

Siwalik and Tarai regions of Nepal lie in southern part of Mahabharat range, respectively occupying $13 \%$ and $14 \%$ of the total land area of the country (LRMP, 1986). Tarai region is boardered with India in the south. Siwalik and Tarai are unique in terms of physiographical, biological and ecological characteristics (Pokhrel, 2013). Siwalik Hills are geologically young. Soils in this area originate from soft rocks and are dry (except during monsoon season). The lower Siwalik region is largely composed of finegrained sediments such as variegated mudstone, siltstone and shale with smaller amounts of fine-grained sandstone (Upreti, 1999). The middle Siwalik has thick beds of multistoried sandstones altering with subordinate bed of mudstone. The upper Siwalik is characterized by the presence of very coarse sediments such as loose boulder conglomerates with minor proportions of mudstone intercalations (Upreti, 1999).

The soils of the Siwalik and Tarai are associated with active and recent alluvial plains, fan and ancient river terraces, depositional basins (Dun valleys), flat, moderately to steepy sloping terrains; and steepy to very steepy sloping hilly terrain (LRMP, 1986). Soils commonly found in the Siwalik region include Cambisols (Eutric and Dystric), Fluvisols, Gleysols, Phaezomes, Regosols and Luvisols, and in Tarai regions are Ustorthents, Ustifluvents, Ustochrepts, Haploquepts, Haplustolls (ISRIC, 2009) that are prone to erosion.

\section{Soil quality issues in Siwalik and Tarai region}

Soil erosion is one of the key environmental issues of Nepalese ecosystems. It is associated with the concerns related to loss of top soil, decrease of soil water capacity and reduced growth of vegetation (Zhou et al., 2006). Siwalik region of Nepal is one of the fragile and vulnerable ecosystems in the Nepalese Himalaya, where soil erosion, landslide and land degradation are the fundamental issues (Ghimire et al., 2013). These transitional mountains extend larger spatial coverage (Singh et al., 2001). Dalling and Tanner (1995) have shown that these regions exhibit low nutrient status due to removal of forest vegetation.

Siwalik range is usually made up of alluvial deposits. The erodible nature of conglomerates and sandstone, coupled with the steep terrain and porous soil, contributes to the fragile nature of the Siwalik region. Forest fires and disturbances due to floods are other important factors in this region (Dhital, 2009). The studies have reflected that human activities are the ultimate cause of this rapid loss of forest and biodiversity, as demand for land and other resources increases with the unprecedented growth of population (Gorenflo \& Brandon, 2006; McKee, 2003; UNDP et al., 2000). Similarly, Tarai region consists of recent and post-pleistocene alluvial deposits which form a piedmont plain south of the Himalayan. In the south of Tarai, it is bordered by the Indian Gangetic plain and in the north there is the Siwalik region. Its elevation ranges from 63 to $330 \mathrm{~m}$ above mean sea level (LRMP, 1986). Loss of forest including native species can have negative impacts on the functioning and stability of ecosystems including the changes that occur in soil quality (Brown et al., 1999; Chauhan et al., 2014). Also, the flood (splash, sheet and rill erosion) in the area causes loss of large amount of nutrients downstream. Similarly, slope length and steepness, surface soil condition, amount of rainfall are important factors determining the rates of soil erosion. Apart from these, particle size distribution and effect of slope exposition have substantial influence on soil erodibility and development of erosion features in Nepal (Shrestha, 1997). The information on soil quality therefore is required for understanding ecosystem health and integrity.

\section{Soil quality and issues in Siwalik region}

Siwalik region of Nepal is vulnerable and prone to soil erosion (Karn, 2007). The soil loss is also due to landslides in the area. According to Ghimire et al. (2013) erosion rates vary significantly within different land use types in the area. In barren land, up to $7.0 \mathrm{~mm} \mathrm{yr}^{-1}$ mean soil erosion has been reported (Table 1).

Table 1 Annual mean (sheet) erosion rates in Siwalik region

\begin{tabular}{ll}
\hline Land Use & Erosion $\left.\mathbf{( m m ~} \mathbf{~ y r}^{-1}\right)^{*}$ \\
\hline Partially dense forest & $1.0 \pm 0.6$ \\
Shrub and bush & $0.8 \pm 1.8$ \\
Dense forest with shrub & $1.2 \pm 0.7$ \\
Bare land & $7.0 \pm 3.8$ \\
\hline Source: Ghimire et al. (2003); * Standard error limits are the 95\% confidence \\
$\quad$ interval
\end{tabular}

\section{TU-CDES}


Soil organic carbon of different regions of Siwalik has been shown in Figure 1. The standard error estimates shown in the figures are $10 \%$ of the mean soil organic carbon estimates. The average soil organic carbon (SOC) in the Siwalik region was $31.9 \mathrm{t} \mathrm{ha}^{-1}$, with the Far-western region having the highest value $\left(35.5 \mathrm{tha}^{-1}\right)$ and the Mid-western region having the least value $\left(27.40 \mathrm{t} \mathrm{ha}^{-1}\right)$. The average organic carbon (OC) content in litter and debris was 0.31 $\mathrm{t} \mathrm{ha}^{-1}$ (FRA/DFRS, 2014a).

Among the forest types of Siwalik region of Nepal (Table 3), KhairSisso (Acasia-Dalbergia) forests was observed with high bulk density. Pine Forest stands were determined to have higher average SOC content (Table 2). The comparisons however are risky, as data taken are relatively unbalanced (FRA/DFRS, 2014a).

Nirola and Jha (2011) studied the soils of Siwalik Hills (of eastern Nepal) and they analyzed different physical and chemical properties of regenerating forest, mature forest and degraded forests. They observed organic matter, nitrogen, phosphorus and potassium content higher in mature forest than regenerating forest and degraded forest (Table 3). This might be due to comparatively stable nutrient dynamics in mature forests.

Similarly, Singh et al. (2001) studied the physico-chemical and microbial aspects of soils in moist tropical Sal forest ecosystem of Eastern Siwalik region of Nepal. They determined increased accumulation of soil microbial biomass and high $\mathrm{N}$-mineralization rate with increasing time lag and maturity of successional stages of disturbed landscapes indicating self re-establishment capability of soils in the area.

\section{Soil quality and issues in Tarai region}

Soils of Tarai areas are also prone to erosion. Large amount of soil gets eroded every year sweeping away larger amount of top soil. The loss of top soil reduced amount of available nutrients from the soil. According to FRA/DFRS (2014b), the Tarai region has average $S O C$ value 33.3 t ha $^{-1}$ with the Central region having highest value $\left(39.3 \mathrm{t} \mathrm{ha}^{-1}\right)$ and the Western region having the least value $\left(18.7 \mathrm{t} \mathrm{ha}^{-1}\right)$. The average organic carbon content in litter and debris has been reported to be $0.26 \mathrm{t} \mathrm{ha}^{-1}$, with the Central region having the highest value (0.35 $\left.\mathrm{t} \mathrm{ha}^{-1}\right)$ (Fig. 2).

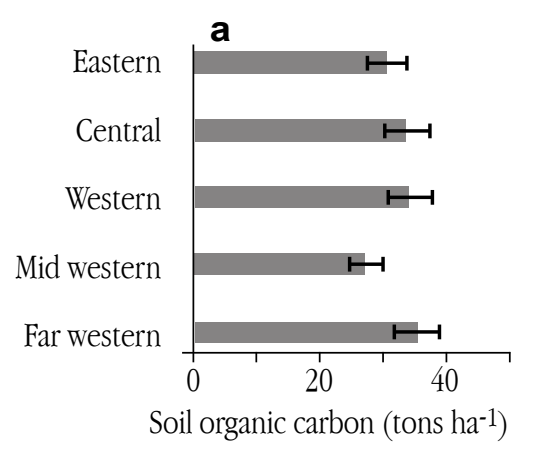

Among the forest types in Tarai regions of Nepal, Sal Forest and Mixed Hardwood forests have very similar SOC content, and the average SOC in Sal forest and Sal Mixed Hardwood was lower than the other forest types (Table 4).

Chauhan et al. (2014) studied the physico-chemical properties of soils of Western Chitwan of Nepal. They analyzed soil physical and chemical properties and determined soil texture, bulk density and textural class for the pasture and forest lands. In terms of soil texture, they reported slightly higher silt and clay percentage in forest soils as compared to pasture soil. Similarly, bulk density of forest land was reported to be higher. Though soils of both regions were loamy, the difference in bulk density was higher in the forest (Table 5). The study shows pasture soil has higher soil organic matter, nitrogen and phosphorus content than the forest soils. But, potassium content was higher in forest soil as compared to the pasture soil (Table 6).

Paudel and Shah (2003) studied the soils in tropical Sal forest of eastern Nepal (Tarai). The study considered Sal and mixed Sal forest for the study and reported soil in both forests to be acidic (Fig. 3). Water holding capacity (WHC) was reported to be higher for mixed forest than for the pure Sal forest (less overlap of standard error bars). The humus content of the soil in two forests was not substantially different, though it was slightly higher in pure Sal forest than the mixed Sal forest. Similarly, the study reflected higher percentage of organic matter $(\mathrm{OM})$ content in the soil of the pure Sal forest. The study reported mean soil nitrogen, available phosphorus and available potassium contents in both the forests to be similar (Fig. 4). There seems similarity in the nutrient content based on overlap in the standard errors between treatments.

Organic carbon is one of the most important component in forest soils. Plant and animal residues, cells of micro-organisms, stable humus and higher carbonized compounds such as charcoal, graphite and coal (Nelson \& Sommers, 1996) contribute to soil organic matter. Soil organic matter plays important role in determining the fertility and productivity (Feller \& Beare, 1997).

Figure 1 Average OC in forest by development regions of Siwalik zone (a) in soils (b) in litter and woody debris (data available from FRA/DFRS, 2014a)

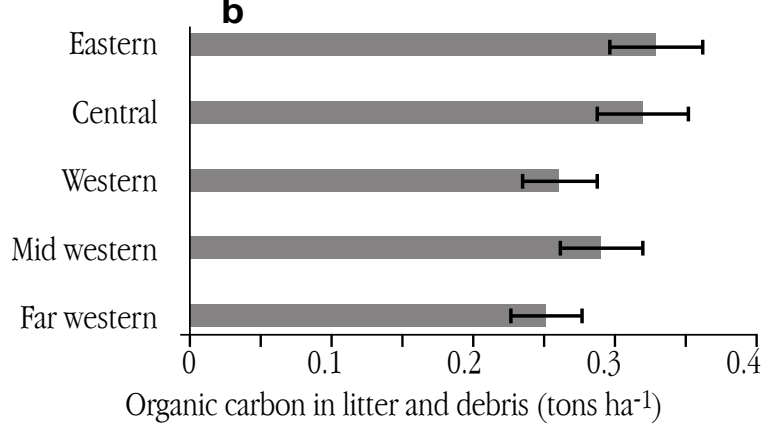


Forest floor is a major storage of organic matter content and other nutrients and serves as an important structural and functional component of the forest ecosystems (Covington, 1981). Plant leaf and root litter are the major organic portions in soils of forest ecosystems which undergo changes mineralization (Sollins et al., 1996). Formation of soil and consequent development of physical, chemical and biological characteristics depends also on the soil forming factors such as parent material, climate, topography, organisms and time (Hans, 1994). Parent material can be rock or the remnants, which has been moved by wind, water, ice or gravity. In forests, the nature of parent materials determines the soil aggregate characteristics. Climate influences soil characteristics in the ecosystems. Similarly, variation in topography also affects moisture and temperature relations. Slopes with southern exposure are warmer and drier than slopes with a northern exposure. The soils in hills are usually with shallower depth and valleys have darker and deeper soil horizons.

Similarly, time is an important factor affecting weathering of parent materials and consequently the aggregation of particles to give characteristic physical, chemical and biological properties. Soils of forests can be referred to as young, mature and old based on time scale of formation and varies with locations. Soil organisms also play important role in characterizing soil properties (Ingham, 1995). Particularly, the role of micro-organisms is very important. The microbial communities are most diverse and abundant in soils but their diversity is poorly understood (Fierer \& Jackson, 2005), even in the soils of Siwalik and Tarai regions of Nepal.

Table 2 Estimates of bulk density, soil organic carbon, litter and debris by forest type in Siwalik region.

\begin{tabular}{lllllc}
\hline \multicolumn{1}{c}{ Forest type } & $\begin{array}{c}\text { Bulk density } \\
\left(\mathrm{g} \mathrm{cm}^{-3}\right)\end{array}$ & $\begin{array}{c}\text { SOC } \\
\text { (\% fine fraction) }\end{array}$ & Stones (\%) & SOC ( $\left.\mathrm{t} \mathrm{ha}^{-1}\right)$ & $\begin{array}{c}\text { Litter and woody } \\
\text { debris }\left(\mathrm{t} \mathrm{ha}^{-1}\right)\end{array}$ \\
\hline Khair-Sisso/Sisso-Khair & $1.34(0.07)$ & $1.33(0.12)$ & 31.2 & $19.7(43.06)$ & 0.17 \\
Lower Mixed Hardwood & $1.25(0.01)$ & $1.58(0.02)$ & 5.2 & $36.1(10.13)$ & 0.28 \\
Pine Forest & $1.24(0.07)$ & $2.42(0.54)$ & 15.6 & $52.6(295.24)$ & 0.13 \\
Sal Forest & $1.30(0.001)$ & $1.54(0.003$ & 11.8 & $31.85(1.42)$ & 0.29 \\
Sal Tarai Mixed Hardwood* & 1.25 & 1.78 & 15.0 & 36.30 & 0.36 \\
Tarai Mixed Hardwood & $1.26(0.0002)$ & $1.42(0.001)$ & 8.1 & $31.44(0.66)$ & 0.32 \\
\hline
\end{tabular}

Source: FRA/DFRS(2014a) (values in parentheses for standard errors of the corresponding value. *Due to insufficient clusters, standard error values were not provided for Sal Tarai Mixed Hardwood forest)

Table 3 Physical and chemical characteristics of soils

\begin{tabular}{lccc}
\hline Parameters of Soil & Regenerating Forest & Mature Forest & Degraded Forest \\
\hline $\mathrm{pH}$ & 6.06 & 6.20 & 5.60 \\
OM (\%) & 2.00 & 2.63 & 2.00 \\
Nitrogen (\%) & 0.09 & 0.13 & 0.09 \\
Phosphorous $\left(\mathrm{kg} \mathrm{ha}^{-1}\right)$ & 24.48 & 34.80 & 18.36 \\
Potassium $\left(\mathrm{kg} \mathrm{ha}^{-1}\right)$ & 180.51 & 208.66 & 199.76 \\
Water holding (\%) & 30.99 & 27.27 & 41.75 \\
Fine sand (\%) & 36.30 & 36.40 & 16.22 \\
Silt (\%) & 52.70 & 47.52 & 64.19 \\
Clay (\%) & 11.05 & 15.97 & 19.57 \\
Color & Dark Grey & Light Grey to Yellow & Grey \\
\hline
\end{tabular}

Source: Nirola and Jha (2011)
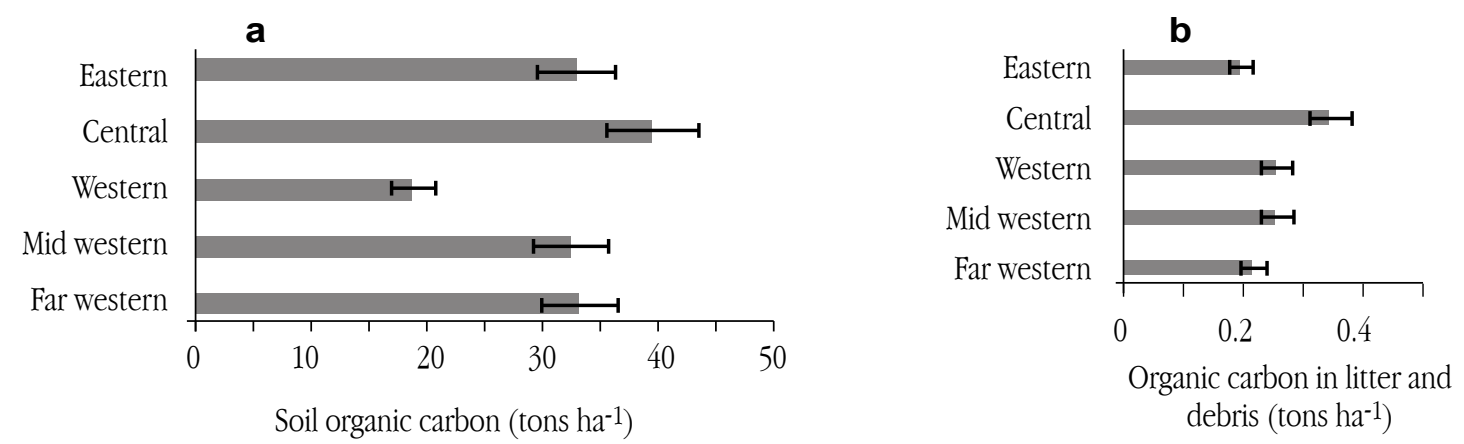

Figure 2 Average OC in forest by development regions of Tarai (a) in soils (b) in litter and woody debris (data available from FRA/DFRS, 2014b)

\section{撚 TU-CDES}


Table 4 Estimates of bulk density, soil organic carbon, litter and debris by forest types in Tarai region

\begin{tabular}{llllll}
\hline Forest type & Bulk density & $\begin{array}{c}\mathrm{SOC} \\
\left(\mathrm{g} \mathrm{cm}^{-3}\right)\end{array}$ & $\begin{array}{c}\text { Stones }(\%) \\
(\% \text { fine fraction })\end{array}$ & SOC $\left(\mathrm{t} \mathrm{ha}^{-1}\right)$ & Litter and woody \\
\hline Khair-Sisso/Sisso-Khair & $1.27(0.03)$ & $0.62(0.02)$ & 0.00 & $24.58(10.72)$ & $0.17(0.001)$ \\
Sal Forest & $1.34(0.001)$ & $0.90(0.003)$ & $3.31(8.49)$ & $33.81(4.67)$ & $0.29(0.0003)$ \\
Sal Tarai Mixed Hardwood* & 1.32 & 0.32 & 22.50 & 12.37 & 0.28 \\
Tarai Mixed Hardwood & $1.36(0.002)$ & $0.94(0.003)$ & $3.63(10.92)$ & $35.74(4.04)$ & $0.29(0.0004)$ \\
\hline
\end{tabular}

Source: FRA/DFRS (2014b) (Note: values in parentheses for standard errors of the corresponding value. *Due to insufficient clusters, standard error values were not provided for Sal Tarai Mixed Hardwood forest)

Table 5 Textural composition of soils in Western Chitwan, Nepal

\begin{tabular}{lccccc}
\hline Category & Sand $(\%)$ & Silt $(\%)$ & Clay $(\%)$ & Bulk density $\left(\mathrm{g} \mathrm{cm}^{-3}\right)$ & Soil textural class \\
\hline Pasture land & 35.95 & 46.92 & 17.13 & 0.99 & Loam \\
Forest land & 34.38 & 47.33 & 18.30 & 1.18 & Loam \\
\hline
\end{tabular}

Source: Chauhan et al. (2011)

Table 6 Chemical properties of soils in Western Chitwan, Nepal

\begin{tabular}{lllcll}
\hline Category & $\mathrm{SOM}(\%)$ & $\mathrm{N}(\%)$ & $\mathrm{P}_{2} \mathrm{O}_{5}\left(\mathrm{~kg} \mathrm{ha}^{-1}\right)$ & $\mathrm{K}_{2} \mathrm{O}\left(\mathrm{kg} \mathrm{ha}^{-1}\right)$ & $\mathrm{pH}$ \\
\hline Pasture land & 4.69 & 0.23 & 15.25 & 72.75 & 5.74 \\
Forest land & 3.42 & 0.19 & 13.00 & 79.50 & 5.36 \\
\hline
\end{tabular}

Source: Chauhan et al. (2014)
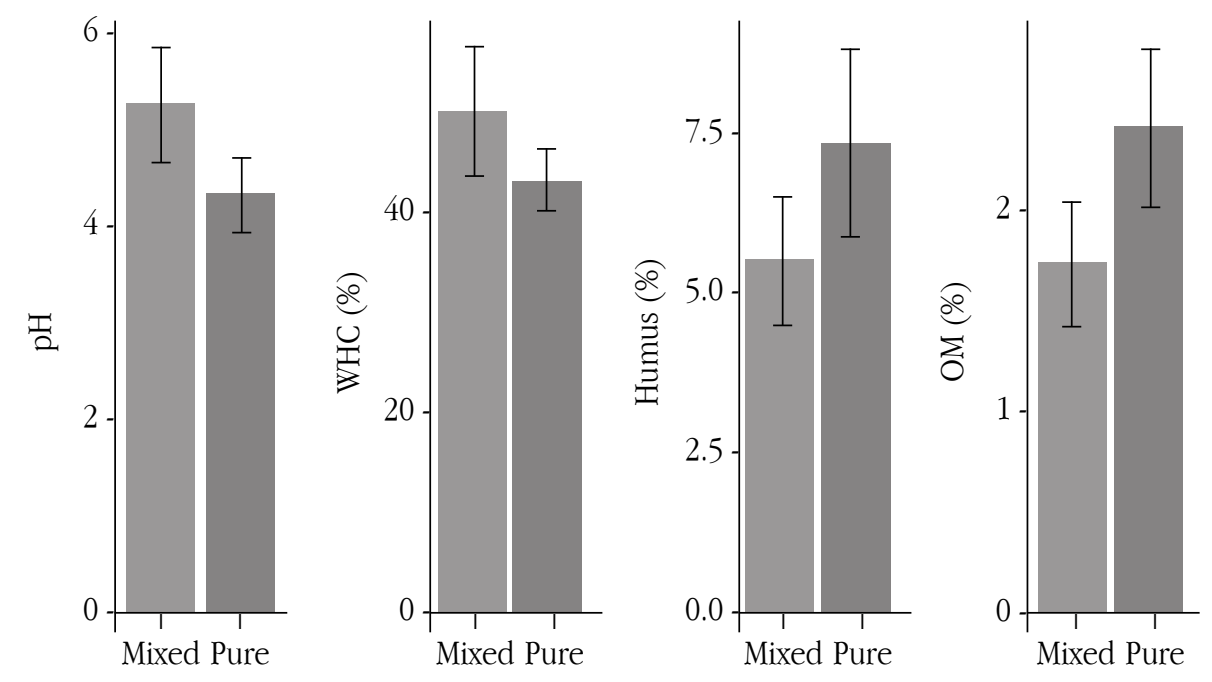

\section{Sal Forest}

Figure 3 pH, WHC, humus and organic matter content of pure and mixed Sal forest (data from Paudel \& Shah, 2003). 

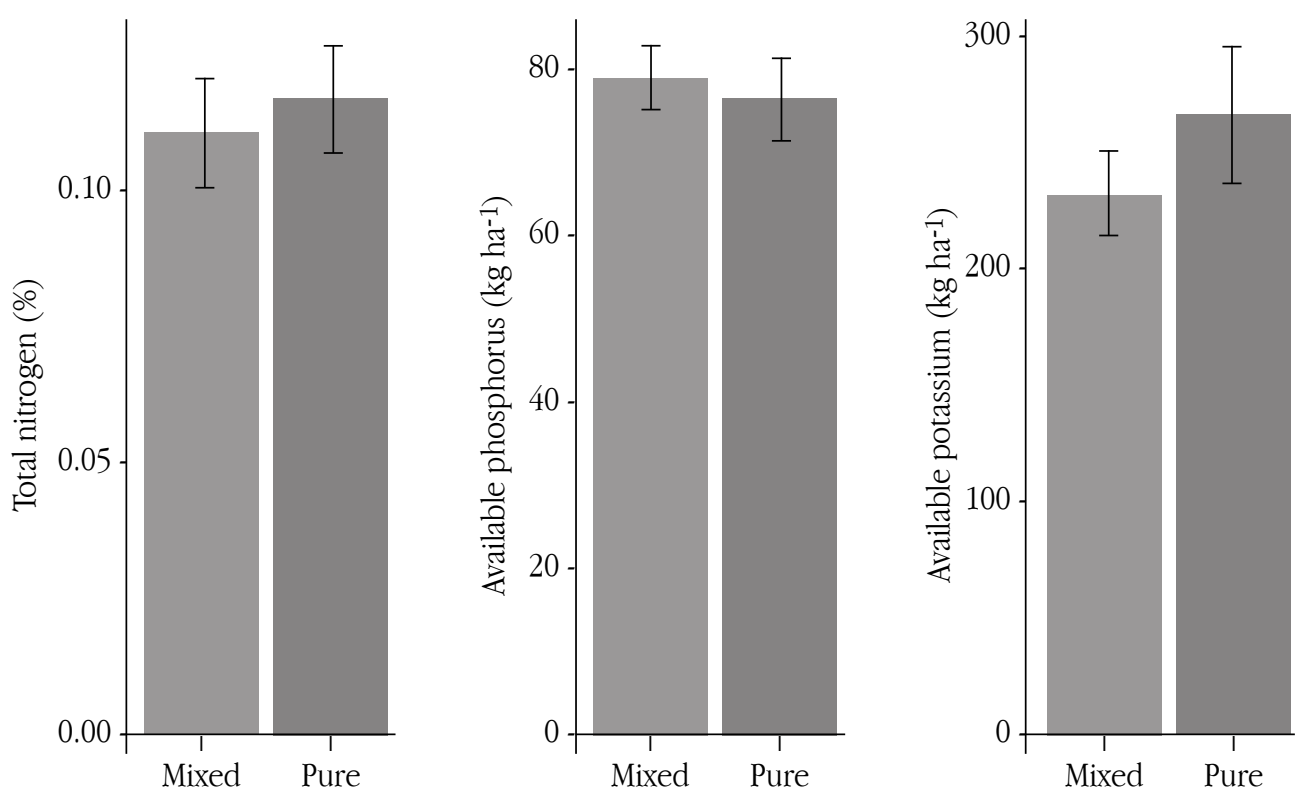

Sal Forest

Figure 4 Nitrogen, phosphorus and potassium contents in soils of pure and mixed Sal forest (data from Paudel \& Shah, 2003)

\section{Conclusion}

The present review reveals that physical and chemical characteristics of soil vary in Tarai and Siwalik regions of Nepal. The land areas covered with vegetation seem effective in controlling sheet erosion and consequently retention of important chemical nutrients of soils. Moreover, the soil quality depends on geographical location, abundance of living organisms (including micro-organisms), variation in relief, difference in catchment aspects and succession stage of the existing forest. However, in context of Nepal, there seems insufficient scientific information on these aspects. Likewise, studies on physical, chemical and biological aspects of soils also seem limited, especially in connection to soil micro-organisms, though these are important component of detritus food chain. Standard research framework and sampling designs are required for the comparisons of soil properties across different degraded forests or land-uses. The scientific baseline and database development would help restoration of the degraded areas and framing of future land management strategies in the country.

\section{Acknowledgements}

The authors would also like to acknowledge Prof. Dr. Rejina Maskey for her valuable suggestion in finding the relevant secondary references. The authors are thankful to Dr. Udhab Raj Khadka for his constructive feedback during preparation of the manuscript. Likewise, the authors are grateful to anonymous reviewers for their contribution in bringing the present paper in this level.

\section{References}

Blake, G.R., \& Hartge, K.H. (1986). Bulk Density: In A. Klute (Ed): Methods of Soil Analysis, Part I, Physical and Mineralogical Methods. American Society of Agronomy, Soil Science Society of America, Madison, WI, pp. 363-375.

Brown, S., Schreier, H., Shah, P.B., \& Lavkulich, L.M. (1999). Modelling of soil nutrient budgets: an assessment of agricultural sustainability in Nepal. Soil Use and Management, 15, 101-108. Chapman, J.L., \& Reiss, M.J. (1992). Ecology: Principles and applications. Cambridge, Cambridge University Press.

Chauhan, R.P., Pande, K.R., \& Thakur, S. (2014). Soil properties affected by land-use systems in Western Chitwan, Nepal. Int. J. Appl. Sci. Biotechnol., 2(3), 265-269.

Covington, W.W. (1981). Changes in forest floor organic matter and nutrient content following clear cutting in Northern Hardwoods. Ecology, 62(1), 41-48.

Dahal, R.K. (2006). Geology of Nepal. Retrieved October 26, 2017 from www.ranjan.net.np.

Dalling, J.W., \& Tanner, E.V.J. (1995). An experimental study of regeneration on landslides in Montane rain forest in Jamaica. J. Ecol., 83, 55-64.

Das, S.K., \& Varma, A. (2011). Role of Enzymes in Maintaining Soil Health, In G. Shukla and A. Varma (Eds.), Soil Enzymology. Soil Bio. 22.

Dhital, N. (2009). Reducing Emissions from Deforestation and Forest Degradation (REDD) in Nepal: Exploring the Possibilities. Journal of Forest and Livelibood, 8(1), 57-62. 
Ewing, S.A., \& Singer, M.J. (2012). Soil Quality. Retrieved October 26, 2017from http://www.oregonsoils.org/wordpress/wpcontent/uploads/2012/01/b11268.pdf.

FAO (1993). Integrated Plant Nutrition Systems, In R. Dudal and R.N. Roy (Eds.), Plant Nutrition Management Service. Food and Agriculture Organization, Rome, Italy.

Feller, C., \& Beare, M.H. (1997). Physical control of soil organic matter dynamics in the tropics. Geoderma, 79, 69-116.

Fierer, N., \& Jackson, R.B. (2005). The diversity and biogeography of soil bacterial communities. PNAS, 103 (3), 626-631.

FRA/DFRS (2014a). Churia Forests of Nepal (2011 - 2013). Forest Resource Assessment Nepal Project, Department of Forest Research and Survey, Kathmandu, Nepal.

FRA/DFRS (2014b). Tarai Forests of Nepal (2010 - 2012). Forest Resource Assessment Nepal Project, Department of Forest Research and Survey, Kathmandu, Nepal.

Ghimire, S.K., Higaki, D., \& Bhattarai, T.P. (2013). Estimation of soil erosion rates and eroded sediment in a degraded catchment of the Siwalik Hills, Nepal. Land, 2, 370-391.

Gorenflo, L.J., \& Brandon, K. (2006). Key Human Dimensions of Gaps in Global Biodiversity Conservation. BioScience, 56 (9), 723-731.

Griffiths, B.S., Spilles, A., \& Bonkowski, M. (2012). C: N: P stoichiometry and nutrient limitation of the soil microbial biomass in a grazed grassland site under experimental $\mathrm{P}$ limitation or excess. Ecological Processes,2012, 1-6.

Hans, J. (1994). Factors of Soil Formation: A System of Quantitative Pedology. Dover Publication Inc., New York. Retrieved October 10, 2017 from http://www.nrcs.usda.gov/wps/portal/nrcs/detail/ soils/edu/kthru6/?cid=nrcs142p2_054311.

Ingham, E.R. (1995). Soil Organisms, Bacteria, Fungi, Protozoa, Nematodes and Rotifers. Retrieved October 16, 2017 from http://www.icbemp.gov/science/ingham.pdf.

ISRIC (2009). SOTER database for LADA partners countries. Retrieved March 10, 2017 from www. isric. org/UK/About+Soils/ Soil+data/Geographic+data/National/default htm.

Karn, P.K. (2007). A Study Report on Economic Valuation of the Churia Region. Technical report assisted by IUCN and CARE Nepal, Kathmandu.

LRMP (1986). Land utilization report. Land Resource Mapping Project, HMG/Nepal.

McKee, J. (2003). Sparing Nature: The Conflict between Human Population Growth and Earth's Biodiversity. New Brunswick (NJ): Rutgers University Press.

MoFSC (2014). Fifth Assessment Report to Convention on Biological Diversity. Ministry of Forests and Soil Conservation, Kathmandu, Nepal.

Murad, O.F. (2012). Obtaining Chemical Properties through Soil Electrical Resistivity, Journal of Civil Engineering Research, 2(6), 120-128.
Nelson, D.W., \& Sommers, L.E. (1996). Total carbon, organic carbon and organic matter, Methods of Soil Analysis, Part 3, Chemical Methods. Soil Science Society of America and American Society of Agronomy, USA.

Nirola, R., \& Jha, P.K. (2011). Phyto-diversity and Soil Study of Siwalik Hills of Ilam, Nepal: An Ecological Perspective. Ecoprint, 18, 77-83.

Osman, K.T. (2013). Physical properties of forest soils. In Forest Soils, Springer, Cham.

Paudel, S., \& Sah, J.P. (2003). Physiochemical characteristics of soil in Sal (Shorea robusta Gaertn.) forest in Eastern Nepal. Himalayan J. of Sciences, 1(2), 107-110.

Pokhrel, K.P. (2013). Chure forestry conservation and management plan: A case study of Arghakhanchi district, Nepal. Jour. of Geography and Reg. Planning, 6(5), 172-183.

Schoenholtz, S.H., Miegroet, H.V., \& Burger, J.A. (2000). A review of chemical and physical properties as indicators of forest soil quality: challenges and opportunities. Forest Ecology and Management, 138, 335-356.

Shrestha, D.P. (1997). Assessment of soil erosion in the Nepalese Himalaya: A Case Study in Likhu Khola Valley, Middle Mountain Region. Land Husbandry, 2(1), 59-80.

Singh, K.P., Mandal, T.N., \& Tripathi, S.K. (2001). Patterns of restoration of soil physicochemical properties and microbial biomass in different landslide sites in the Sal forest ecosystem of Nepal Himalaya. Ecological Engineering, 17, 385-401.

Silver, W.L., Neff, J., McGroddy, M., Veldkamp, E., Keller, M., \& Cosme, R. (2000). Effects of Soil Texture on Belowground Carbon and Nutrient Storage in a Low-land Amazonian Forest Ecosystem. Ecosystems, 3, 193-209.

Sollins, P., Homann, P., \& Caldwell, B.A. (1996). Stabilization and destabilization of soil organic matter: mechanisms and controls. Geoderma, 74, 65-105.

Tan, K.H. (2011). Principles of Soil Chemistry. Taylor and Francis Group (International Standard Book Number - 13: 978-1-43981395-9.

[UNDP] United Nations Development Program, United Nations Environment Program, World Bank, World Resources Institute (2000). A Guide to World Resources 2000-2001. People and Ecosystems: The Fraying Web of Life. Washington (DC): World Resources Institute.

UNEP (2009). Converting waste Agriculture Biomass into a Resource. Retrieved October 26, 2017 from http://www.unep.org/ ietc/Portals/136/Publications/Waste\%20Management/WasteAg riculturalBiomassEST_Compendium.pdf.

Upreti, B.N. (1999). An overview of the stratigraphy and tectonics of the Nepal Himalaya. Journal of Asian Earth Sciences, 17, 577-606.

Zhou, Z.C., Shangguan, Z.P., \& Zhao, D. (2006). Modeling vegetation coverage and soil erosion in the Loess Plateau Area of China. Ecol. Model, 198, 263-268. 